\title{
RIGHT OF PRE-EMPTION - HISTORICAL PERSPECTIVE
}

\author{
Vlad lonuț SAVU ${ }^{1}$
}

\begin{abstract}
In this scientific approach, we will focus on the historical dimension of the right of pre-emption. This paper is structured in three chapters highlighting the most important historical aspects underlying the right of pre-emption. Etymologically, pre-emption comes from the Latin words pre (before) and emptio (sale). The first notions of the right of protimis appear in Roman law, where property and inheritance are treated as religious derivations. The great French historian Numa Denis Fustel de Coulanges (1830 - 1889), in his work Cité Antique (Ancient City), stated that property appears to be of divine origin.

It belongs to a family, which includes the protective gods, the dead and the continuators of the family cult, i.e. those who are alive or those who will be born. Each individual of the family is considered a temporary possessor of the property with the obligation to pass these rights on to the descendants in order to continue the family's domestic cult.
\end{abstract}

Key words: subjective right, right of pre-emption, successor, property, sale.

\section{Introduction}

The Romans, as the founders of the established institutions of modern civil law, conceptually developed a subjective right, which gives its holder a preference in the transmission and acquisition of property, known as the right of pre-emption.

Most properties in Italy and Gaul were in a state of undivided ownership, which gave rise to multiple conflicts, especially when in competition with the descended co-owners of the original owner, foreigners came, usually creditors or buyers of the auctioned parts. In order to settle these conflicts, partition proceedings were initiated, and often successor co-owners asked to leave the joint ownership.

There were two solutions for resolving partition proceedings, the first was division in kind or the second, sale of the property, with the price divided between the co-owners. To these two solutions is added a third given by a text of Ulpianus: "Si familiae erciscundae vel communi dividundo judicium agatur et divisio tam difficilis sit poenae

\footnotetext{
${ }^{1}$ PhD Student Titu Maiorescu University, savudanila@gmail.com corresponding author
} 
imposibilis esse videatur, potest judex, in unius personam totam condamnationem conferre et adjudicare omnes res" (Digesta, X, 2, 55 - Familiae erciscundae).

The latest solutions tend to reconcile both views and allow the successor of the original owner, who is co-owner of the property, to acquire the entire property.

\section{Right of Pre-emption}

On some disputes concerning family property, we recall the indications of Emperor Antoninus to Lucian (C.I. 3.37.1. - Communi Dividundo 213 AD), of Emperor Alexander Severus to the soldier A. Avitus (C.I. 3.37.1. - Communi Dividundo year 222), of Emperor Alexander Severus to Verecundianus (C.I. 3.37.1. - Communi Dividundo year 224), in which we find the use of the terms "si frater tuus ... frati tui" (of your brother, ... if your brother ...). In the words of those mentioned above, the petitioners are brothers, coowners of the hereditary property, not strangers (extranei).

They do not attribute the unavailability of the undivided property and the right of revocation to the technique of partition, but to a right, a different and distinct notion, for which a solution is sought in law and possibly a modification of the existing right.

One brother claims to be injured by the fact that the other brother has alienated the inherited property and is thus in joint ownership with a stranger. In all the cases one can see the petitioner's intention to get rid of this stranger and his conviction that the sale made to a stranger without his being asked, i.e. offered to him for purchase, is void and is to be revoked.

The idea of this solution has been given substance and has sufficient value in terms of contemporary moral and religious precepts to even create legal effects.

A hundred years later than the above, we recall the imperial constitutions of Diocletian and Maximian commented by Aurelius Eusebius: "You were wrongly convinced that part of the land in joint ownership (pro indiviso) can only be sold to a co-owner, not to a stranger, before the process of division of the joint property is decided".

Not long after this, Constantine the Great, in 326, said, "But not to allow the house to be sold from which the father was deprived, in which the little one grew up ... is sad, "(C.I. $V, 37,5$ - De administratione tutorum et curatorum et de pecunia pupillari feneranda vel deponenda) who, contrary to Diocletian and Antony, no longer finds this belief false. The text of Constantine the Great's Constitution has not been preserved but there is enough information to restore its meaning.

The first information on this is found in the Constitution of Julian, (year 362): "All the prescriptions which the litigants have invented, under the pretext of the parties, for the purpose of postponing the sentence, having been rejected and abolished, permission is granted to those who have sued to act and to answer, whether they all belong to the same forum (city) or live in different provinces, it not being necessary for a party or parties to be present.

And, the constitution of Constantine, my uncle, having been amended, which was promulgated in relation to the co-inheritors, the old law, so far as it relates to decisions of this kind, being preserved with all firmness, all artificial obstacles being abolished and the ability of those who have taken possession of it, being stopped". 
Then we have the Constitution of Valentinian Gratian and Theodosius which abrogated the Constitution of Constantine the Great (Codex Teodosianus: III - 40.1 ).

From the above analysis, the text of Constantine the Great's Constitution gave the coowners the right to exclude foreigners from buying the lots (sors) of the undivided property, thus establishing in perpetuity the situation created by the initiation of the partition process.

Thus, without the authorisation of the co-owners, without their consent, without their having refused the purchase under the conditions offered by the prospective buyer, the share belonging to a co-owner could not be sold. If such a sale did take place, the coowners had the right to request its revocation.

In favour of cognates (blood relatives) and consorts, a right of priority to purchase is established, a privilege parallel to the privilege of relatives to exclude foreigners from forced sales. Constantine the Great's constitution has long been discussed and commented upon, especially in comparison with that of Constantine Porphyrogenitus or Roman Lecapen.

Some commentators have argued that the text was borrowed by Constantine the Great from either Greek or Mosaic law, while others say it was a "consequence of coownership".

These views expressed basically supported an obvious point: the Constitution on preemption speaks more of its effects. The right conceded was that foreigners were removed from the purchase, and the direct consequence was that the owner could not dispose of his property by sale as he wished.

In Basilicles XIX, it is expressly stated that cognates (blood relatives) and socii (allies) had the right to prohibit their co-owners from alienating (estranging, splitting up) their sors (lots).

This was only recognised if partition proceedings were brought. (See C.J. 3, 37,1)

We are dealing with the same co-ownerships, and co-owners can prohibit the sale. Without their authorisation, the socius (ally) or brother-in-law (blood relative) cannot sell. Until the auction was organised, if the condominium owners (Latin condominii people who exercised their right to the same lot) did not agree on the price offered by the person who wanted to buy the share, negotiations were held between the condominium owners to buy their shares. By right, the outsider (stranger) was removed from the purchase by the co-owners.

Even if the auction took place, it was not done in order to pass the property to a stranger, but to prevent the co-owners from being forced to sell their shares at a price too low: "nonnumquam etiam extraneo emptore admisso, maxime si se non sufficere ad iusta pretia alter ex sociis sua pecunia vincere vilius licentem profiteatur"... (... sometimes even a foreign buyer was accepted, especially if one of the co-owners declared that he did not have enough money to pay the right price or to win with his own money against the one who offered a lower price). In case of an equal offer, the co-owner was preferred to the foreigner, even in the case of an auction.

The right of pre-emption also appears as a consequence of co-ownership, but only within the limits of the Constitution of Constantine the Great. It is not, however, a direct 
consequence of co-ownership, but it is possible to admit the descent of pre-emption from the succession, where there is a right of succession to the integrity of the property.

There was therefore an appropriation in origin and legal nature between succession and co-ownership in the formation of the right of pre-emption.

From all the existing texts, it results that Roman law admitted a right of pre-emption to purchase in favour of relatives and co-owners, the scope and application of which could be sketched as follows: it is exercised only on immovable property, and as an essential condition, the beneficiaries are required to be undivided.

In terms of the degree of preference, the first are the cognate co-owners (blood relatives) and in their absence or when they refuse to buy, the non-relative co-owners come after. Non-co-owning relatives have no right to preference.

It is possible that the co-owning relatives have excluded each other according to their degree of kinship. The right of pre-emption is exercised in free sales. The co-owner who wished to alienate his share, had first to propose it to the co-owners. The existing texts do not indicate any time limit for exercising the right or for making the offer to purchase.

The right of disposal by sale was limited and it was possible for both the foreign buyer and the seller to be in the hands of co-owners. The text of the repeal speaks of "injuria quae inani honestitatis colore velatur" or (honesty that embroiders their colours in repose) and laments the shrinking of the right of disposal.

The abrogation came in 391, after almost 60 - 70 years, for reasons set out in the Constitution of Constantine the Great.

As a distinct right, the right of preference was called by Byzantine jurisconsults: jus protimiseos, or Latin praelatio (right of authority).

In Roman law prelacy does not appear as a direct consequence of family cult or family law. The manifestation of the "right of protimis" in this period aims to give the successor of the original owner an extra chance to keep the ancestral property.

This is the determining active element of the solutions given, which has to some extent become part of the concept of subjective right, recognised "ope legis".

Starting from social, economic and political considerations, Byzantine law takes up the theme of pre-emption.

The seeds of feudal relations have been around since the time of Marcus Aurelius.

This is the period when, through political influence, the Roman nobility and knights accumulated immense wealth without regard for the central imperial authorities, to whom they were subject and obeyed. These authorities were often in their service and helped them to oppress the poor and extend their property and power.

Thus, various authors of the time described how the wealthy formed real states in the Roman State, had their own structures and totally ignored the public authorities (La fin du monde antique).

The "potentates" (those who had become rich) used the poor "tenuiores" - those who had no rights. Oppressed by the powerful, the poor - free people were forced to sell their land and accept the "protection of the potentates". The power of the potentates became a threat to public order as well as to imperial authority. 
Removing this danger required firm measures not only of an administrative and police nature, but also in public and private law.

Thus, the Roman and then Byzantine emperors adopted measures to support the lower classes against the potentates 'ones. They wanted to achieve a balance of power in order to have support in maintaining their order and power. The legislation of the time gives a picture of the traditional politics and the measures adopted.

The measures aimed in particular to prevent the expansion of large, landed estates (Latin latifundii) and to increase the number of small freehold farmers. To this end, the "comendatio" - patronage - is prohibited, so that small farmers are supported to avoid becoming "precarious holders" of the landed estates of the potentate owners.

We recall here the two constitutions of Emperor Constantine the Great $(\mathrm{Cl} .11,58,1)$ and the one given by Zeno. These measures, even if they limited the abuses of the potentates, do not seem to have had the desired effect. So, after these two constitutions, others appeared which directly attacked the institution of patronage and banned it, punishing offenders with various fines.

The first is that of Valentinian Valens and Gratianus from 368 to 370, then Honorius and Arcadius in 399, Marcianus and finally Leo and Anthemius in 468, who give final form to these prohibitions. ${ }^{13}$ These interventions aimed at prohibiting the transfer of small farmers' property into the hands of the potentates.

Thus, in the Constitution of Honorius and Theodosius II of 415, the "transactions extorted by potentates" - ad populum - "venditiones, donationes, transactiones quae per potentiam extortae sunt, praecipimus infirmari ${ }^{14 "}$ ("We recommend that sales, donations, transactions which have arisen as a result of one's power be cancelled") were declared null and void. At the same time, Honorius and Theodosius II establish a special provision for Egypt Cl. 2,19,12 - "De his quae vi metusve causa gesta sunt" (about those who are made out of compulsion or fear).

This time, it is no longer in question whether the alienations are "cauza patrocinii" (cause of protection) or if they are "extortae" (simply squeezed out). It is forbidden to possess in "metrocomii" (in large cities)) to others than "convicanii" (inhabitant of the same city) whose quality is to be established, seriously appreciating "fortunae conditione" (conditions). Free farmers begin to be put in the situation of decurions (Roman cavalry officer), curialii (soldiers of a Roman division - curie - curialii). Their property must pass only to persons of this class. Only a convicanus (inhabitant of the same city) can own in a metrocomie (rank given to a city - metrocomie - big city).

"Si quis post hanc nostri numinis sanctionem in fraudem circumscriptionemque publicae functionis ad patrocinium cuiuscumque confugerit, id, quod huius rei gratia geritur sub praetextu donationis vel venditionis seu conductionis aut cuiuslibet alterius contractus, nullam habeat firmitatem: tabellionibus, qui talia instrumenta perficere ausi fuerint, bonorum proscriptione plectendis, qui tamen scientes ausi fuerint huius modi instrumenta conscribere: vicis etiam vel possessionibus ad patrocinia confugientium publico vindicandis. Eae autem personae, quae contra publicam commoditatem in clientelam suam suscepisse collatores detectae fuerint, nobiliores quidem centum librarum auri condemnationem subire cogentur, mediocris vero fortunae facultatum suarum amissione plectentur" Imperatores Leo, Anthemius. "If any one, after this 
sanction made by our order, shall appeal to the patronage of any one for to defraud (a man) with public title, this, which is done for the purpose, or under the pretext of a donation or of a sale or of a lease or of any kind of contract, shall be declared void: notaries who have dared to make such acts and especially those who, knowingly, have attempted to draw up instruments of this kind, must be punished by confiscation of property: the villages and even the property of those who appeal to patronage must be confiscated. But those persons found to have taken taxpayers under their protection, against the public interest, will be punished: the nobles will be forced to pay a fine of 100 pounds of gold, but the middle class will be condemned to the confiscation of their wealth".

In 468 Leon and Anthemius establish compulsory measures on the whole empire, by applying these measures, small farmers are grouped into communities and organized into corporations, making them an important political tool, defended and protected by the Roman and Byzantine emperors. According to the provisions of Leo the Wise, "no one but the convicans (fellow villagers), the poor small farmers, could either acquire or possess within the boundaries of the vicus (a settlement in the vicinity of a Roman castrum)".

The potentates could not extend to the villages under any circumstances, they had to remain in their corporation and class just as the peasants, the military, the scribes (hand writers) had to remain in their class.

A political balance is thus achieved in the imperial administration. The right of monopoly is abrogated by Leon the Wise, and by this measure the covincans have the right of monopoly on the purchase of goods within the vicus to which they were "adscripti" (enrolled), i.e. his name was written after the good, and this was opposable to any outsider. When the right of monopoly was abrogated by Leo the Wise, a right of pre-emption, of protimisis, remained in their favour as a consequence of this right.

It is believed that Leon the Wise after several socio-political and historical events was prompted to amend this legislation. Political infighting to strengthen the dynasty, the divorce and his third marriage forced him to make a lot of concessions to the potentates. See the Novella of Leon the Wise which we find in a source in Romanian, and the text representing practically the starting point of protimisis in Byzantine law.

The paternity of the right of pre-emption is to be attributed to Leo the Wise and not to the emperors who succeeded him to the throne of Byzantium, and the regulations given only perfected the legislation in this regard with the obvious tendency to return to the old system, to absolutely prohibit the purchase of land by the powerful from the poor.

Thus, Leo the Wise by Novella LXXXIV (84) abrogated in part the provisions of Justinian's Constitution, prohibiting civil, military and ecclesiastical (clerical) officials from acquiring property and borrowing money in the constituency where they held office, thus introducing a special incapacity.

This Novella, as well as the reform of the right of pre-emption, had adverse consequences for small Byzantine farmers. After the death of Leo the Wise, a great famine broke out, and the "potentiores", taking advantage of the plight of the poor, expanded their holdings as much as possible by means that did not correspond to the 
morals of the time. They often took advantage of the fact that they held important positions in the state and thus forced the will of the sellers.

To right this wrong, Roman Lecapen (Emperor of Byzantium between 920 and 944) establishes a first measure by Novella 935, which contains moral and religious considerations, which basically restores the right of pre-emption, stopping the uncontrolled growth of large estates.

Unfortunately, this law was boycotted by the imperial bureaucracy, which was in the hands of the rich. It was necessary for the emperor to repeal Leon the Wise's Novella 84 and pass a new law in Sept. 934, which decided to restore lost property free of charge if the price for it was less than half the normal price. This law of 934 was not fully implemented either, and was also boycotted by those concerned.

After the two Novellae of Roman Lecapen, the new emperor Constantine Porphyrogenitus sought to give a permanent character to the right of pre-emption by drawing inspiration from his predecessor's Novella of 935.

Constantine Porphyrogenitus sought to extract from the earlier legislation what had emerged as durable and experienced, thus applying the right of pre-emption to both the provisions of Constantine the Great's Constitution regarding degrees of pre-emption and the provisions of Roman Lecapen's Novella regarding classes of retractors.

He seeks to ensure that the right of pre-emption is not a means of extending the large ownership and that someone, who knows that only he can become the owner of a property by sale, comes into possession of it, thus forcing the sale.

The principle from which the legislator proceeds is the same throughout the Novella: the small and weak must be protected in the maintenance of his property wherever the attempt to dispossess him comes from.

Constantine Porphyrogenetus adopted the old policy of the later Roman and Byzantine emperors, which consisted in protecting and encouraging the agrarian class to the detriment of the potentates.

Any attempt to circumvent the law, if the alienations were made by donations or any kind of simulated deeds, in which the right of pre-emption could not be exercised, were null and void, and the offender was subject to oath and punished as a perjurer (person who swears falsely or violates his oath).

If the fact was admitted, both the buyer and the seller lost the price and the object of sale, and the goods were sold by the tax authority to those who had the right of preemption. This provision takes the right of pre-emption out of the common law, where failure to comply with it could lead only to the invalidity of the deeds performed and not to the confiscation of the price and the object.

At this stage, the right of promitis takes the form of "public policy", with the State and society having an interest in the strict application of the law.

These documents confirm that the Byzantine emperors used the right of pre-emption as a tool to balance social forces and as a weapon against the possible opposition of the great feudal lords, supporting the element most favourable to imperial rule. 


\section{References}

Chelcea, S., Ivan, L. \& Chelcea, A. (2008). Comunicarea nonverbală: gesturile și postura. Cuvintele nu sunt de-ajuns [Nonverbal Communication: Gestures and Posture. Words are not Enough]. Bucharest: Comunicare.ro.

C.I. 3.37.1. - Communi Dividundo - On the division of a common property.

C.I. 3.37.2. - Communi Dividundo - On the division of a common property.

Codex Teodosianus: III - 40.1

Costăchescu, M. (1931). Documente moldovenești înainte de Ștefan cel Mare [Moldovan Documents before Stephen the Great]. $1^{\text {st }}$ volume. Iasi: Viața Românească

*** Cnejii Români (The Romanian knyaz). Bucharest: Romanian Academy, Annals of 1904

Dictionary. Bucharest: Publishing House of the Academy, p. 390-392.

*** Digesta, X, 2, 55 - Familiae erciscundae - On the division of inherited wealth.

Esmein - "Histoire du droit francais" (History of French Law).

Ferrero, G. (1906). Grandeur et décadence de l'empire roman. La fin du monde antique. Paris.

*** Pandectele Române [Romanian Pandects Magazine] (1928) - year 5, chapter 8. Bucharest: Ziarul Universul Publishing. 